Portraits of work: mapping emerging coworking dynamics

Peer-reviewed author version

CONSTANTINESCU, Teodora \& DEVISCH, Oswald (2018) Portraits of work:

mapping emerging coworking dynamics. In: Information, communication \& society, 21 (9), p. 1263-1278.

DOI: $10.1080 / 1369118 X .2018 .1459775$

Handle: http://hdl.handle.net/1942/25923 


\title{
Portraits of work: mapping emerging coworking dynamics
}

\begin{abstract}
Today's patterns of work are very much defined by the 'lean enterprise' practice, taking form in organizations that are more competitive, customer-driven and agile on the one hand (Womack, J. P., \& Jones, D. T. (2007). Lean Solutions. New York: Simon \& Schuster), and the separation of work from time and space on the other (Hochschild, A. (1997). The time bind. New York, NY: Metropolitan Books). Concepts like work and workspace are subject to an evolving nature and get a new meaning (Kirsh, D. (2000). A few thoughts on cognitive overload. Intellectia, 1(30), 19-51). This triggered the rise of new working spaces, fuelled by the aftermath of the global economic crisis that transformed the practices and meanings of work. Nevertheless, this applies only to particular sectors. This paper builds on the case of Genk, an important economic pole in the Limburg Region of Belgium. The development in the region has always been related to labour-intensive industrial activities. In light of these working shifts targeting mainly big companies/employers, Genk has turned a blind eye on the local proprietors. What about the small entrepreneurs/community economies addressing mainly the local clientele? What evolution do we see in their working pattern? By using a specific visualization tool, a series of interviews were conducted in order to explore in a playful way, existing social and economic networks. The interviews reveal networks that shape a coworking model. The paper will further present the scale of this 'coworking' phenomenon experienced in Genk, perceived to be the 'new model of coworking' in the context of the collaborative and sharing economy.
\end{abstract}

Key words:

Coworking; play; socioeconomic networks; work dynamics; capacity building 


\section{Introduction}

What we see today is a triumph of what we call neo-liberalism - the term refers to liberalism in the eighteenth century meaning: free markets, individualism, limits on government, regulations, saying in some sense that every individual is out for him/herself, the triumph of conservative market economics - believing in growth above all things. Due to the recognition technology and organizational models applied from the economic sector, new patterns of work are emerging to develop their full potential. Nevertheless, they have not yet resulted in a specific new model for work, but more in a bundle of different models developing simultaneously, based on the different nature of organizations, work practices, culture and customers (John J. Heldrich Center for Workforce Development, University of Connecticut. Center for Survey Research \& Analysis, 2000; Arvidsson, 2008). Equally, these changes apply only to specific sectors and/or businesses. Our case study looks at small entrepreneurs whose business model did not change that much over time. We label them as community economies. As they did not undergo major changes in the past years, not much attention has been paid to their working model, nor working scale. In the larger discourse of work, collaboration and collective activity become more dominant and workers need to develop better social skills to cope with conflicts and negotiations arising from various teamwork; they need to be better equipped to develop interpersonal relationships and be more open to sharing and developing ideas together - networking (Gill \& Pratt, 2008). This trend led to the co-working phenomenon. Social and interactive competences are essential assets to successfully participate in today's work environment. Given these virulent changes, new methods are required to investigate whether the same evolution applies to these community economies.

Specifically, we analyse their work network and try to understand the different work types that emerge, guided by the following questions: '(how) Are small local entrepreneurs adapting to the larger discourse of co-working?' and 'Can community economies generate different types of work?' After introducing the concept of co-working, we focus on a particular case study. We present the process of visualizing different socio-economic networks of work in a participatory mapping process. This unveils a particular scale of work dynamics and a more nuanced model of co-working. We conclude with reflections on this model.

\section{The rise of co-working}

The 1900s work philosophy was defined by Ford's assembly line production. He introduced a new model in the manufacturing process that consisted of fixed workstations. This process was further developed and allowed scale and variety, controlling and producing smaller production quantities with a focus on quality - the lean enterprise. It further grew in the mass production principle with focus on diminishing variability by reducing time, pollution, production costs, increased customer satisfaction and increased profits (Womack, Jones, \& Roos, 1990). Focused on the creation of valuable output from the customers' perspective with minimal waste and processes, it fuelled changes in organizations across the globe (Watson, 2012). These principles originated from the model that outdated the mass production system of Ford and combined the operational quality with valuebased strategies towards a supported growth. Nothing is produced without an order from the customer, and to achieve perfection, non-value-added activities are eliminated systematically and continuously from all production processes (Womack \& Jones, 2007). The internet and software technologies of the 1990s and 2000s moved the innovation realm away from the electronic manufacturing. Companies started to develop new products under the principles of lean enterprise and agile software based on validated customer demand - Lean start-ups (Howard, 1995). After 2010, non-internet companies could enter into new markets by adopting the Lean start-up principles. They could now offer goods and services 
with less time, labour and capital. For internet and software companies, these principles support them in remaining competitive and maintaining internal innovation. Today's changing patterns of work are subject to many factors. Nevertheless, two key drivers are brought forward by theorists: (1) the 'lean enterprise' practice - organizations have to be more competitive, customer-driven and agile (Womack \& Jones, 2007) and (2) the separation of work from time and space (Hochschild, 1997). At the end of Ford epoch (1990s to 2000s), 'innovation networks' - co-working spaces - took over the old industrial clusters; these modern networks integrate microbusinesses whereby larger companies operate as 'anchors' to bring new businesses into the cluster. The main purpose of co-working spaces is to provide network intermediation and physical spaces for the work life activity (Capdevila, 2013).

After the revolution in information and communication technologies, work undertook substantial changes in the past decades due to the breakdown of connectivity barriers (Womack \& Jones, 2007). The growing technology pushes forward virtual communication methods that allow increased isolated interaction while digitizing human senses and diminishing the pressing need for physical interaction (Kling \& Zmuidzinas, 1994). The work output is mostly digital, thus concepts like 'work space' and 'work place' are subject to an evolving nature and get a new meaning as we dive deeper into the information age (Kirsh, 2000). Work today is more dependent on cognitive complexity, team-based activities, social skills and technological abilities; it is subject to time, more mobile and less reliant on geography (Cappelli \& Keller, 2013; Osnowitz, 2010). Collective work forms and spread organizations started to appear under the name of 'co-working spaces'. A new possible way of working was developing as a halfway combination between the classic work life, in a defined, traditional space as a traditional community environment, and the freelancer independent work life. This new method of work was called coworking, expressing individual work in a shared environment, to separate its meaning from co-working (with hyphen), which involves working together on the same work project (Fost, 2008) the two terms are often substituted with each other, though. The first community-oriented spaces, offering a physical location where people can meet and work, C-Base, appeared in Berlin (1995) (Lange, 2006; Lange, 2011; Foertsch \& Cagnol, 2013; Moriset, 2014) and promoted free public access to the internet. In 1995, C-Base provided hackers with a community and facilities to pursue their computeroriented ventures, inadvertently setting the foundation for community-oriented spaces where people with a common interest (computers in this case) could gather to collaborate and work in an open environment (Moriset, 2014).

Even though cooperative arrangements, such as mutual insurance and principles of cooperation existed long before, alternative ways of organizing industry, work and employment started appearing at the beginning of the nineteenth century (Birchall, 1997). The industrial revolution and the increasing mechanism of the economy transformed society and threatened the security of many workers. Britain and France were the first countries to react, and the cooperative movement started to take shape with the application of cooperative principles to business organization (Birchall, 1997). One of several early English cooperative ventures, the 'anti-mill' flour mill in Hull, was set up in 1795, by local people. They 'rebelled' against high prices charged by commercial millers. The 'anti-mill' carries on operating for a century. The first significant national cooperative congress held in 1831 in Manchester brings to the fore discussions about a national wholesale operation. Hundreds of local coop societies are established around this time; however, many are short-lived. The opening of the Pioneers' shop in 1844 belonging to the Equitable Pioneers cooperative society becomes accepted worldwide as the start of the modern coop movement, a strongly working-class movement. The first specific legislation for cooperatives is set in motion in 1852 when the Industrial and Provident Societies Act is passed, bearing the same name today. Spurred on by the success of putting his workers in a good environment with access to education for themselves and their children, Robert Owen introduced the idea of forming 'villages of cooperation' where workers would grow their own food, make their own clothes and become self- 
governing. He tried to form such communities in Scotland and in the United States; however, both failed. In other countries, such as Russia, the village cooperative operated from preserfdom times until the twentieth century (Thompson, 1994). Germany developed the credit union, an independently formulated cooperative model. This model reached the United States in the 1880s and, by 1920, the country had formed a national association.

During the 1970s, development of workers' cooperatives (specifically in wholefoods, bookselling, graphic design and printing) makes way for a new generation of political activists. Co-working spaces are an example of such cooperative forms of working, bringing together all kinds of knowledge workers (freelancers mostly) and owners (hosts) as partners, with various skills in 'distributed work', in network-based and collaborative systems of production (Spinuzzi, 2012). This 'hybrid' interaction framework that acted as a 'liaison between people, spaces and technologies' (Pratt, 2002), became a contemporary 'product space', due to a most efficient work distribution in time and space and also to a cultural climate fitted into this unconventional environment: socially organized work systems grounded on social networks and tacit or shared knowledge (Pratt, 2002). Cities all over the world show signs of co-working expansion, with regard to initiative and endeavour, in a self-proclaimed 'coworking movement'. This new concept is very well fitted in the post-crisis economy notions, such as 'start-ups', 'social innovation' or 'sharing economy' (Botsman \& Rogers, 2011). Co-working is perceived as a worldwide phenomenon with strong local background characterized by an important element the open-source community approach to work (Leforestier, 2009) - meant to be collaborative and to create some type of communitarian social relations between the workers/members. As such, coworking spaces are collective places, from a value-oriented point of view, in which co-workers function as complementary figures rather than challengers.

\section{Case study}

We will describe a case study to discuss how the integration of a visualization tool in a participatory process can reveal a new spatial scale of co-working dynamics. Our case study: Vennestraat - the main commercial street of Winterslag, one of the core neighbourhoods of Genk (BE).

Genk is part of the larger region of Limburg, the former mining area stretching till the Ruhr region Urban Network Limburg mining district, the Economic Network Albert Canal and the Hasselt Genk Urban Area, thus having an important role as an economic pole and amenities cluster. The development of Genk has always been related to workintensive industrial activities. The discovery of coal at the beginning of the twentieth century leads to an exponential population increase. Winterslag was originally intended for executives, employees and skilled miners. As such, it has developed as a very mixed neighbourhood: a mix of autochthonous and immigrant residents (one in five inhabitants is of non-Belgian origin). With a population density of 2197 inhabitants $/ \mathrm{km} 2$, Winterslag far exceeds the average population density in Genk (742 inhabitants/ $/ \mathrm{m} 2$ ). The neighbourhood was completed in 1924 following the English 'Garden-city' pattern. Typical of Winterslag are the lodging houses, houses where rooms were rented to foreigners coming to work for the mine. A number of lodging houses remain still on some streets (e.g., Vennestraat), where private rooms are often rented at extortionate rates. The closing of the mines in the second half of the twentieth century was anticipated by investing in major infrastructure works and attracting a new multinational, namely Ford. The closure of Ford Genk (2014) puts the city in a second economic crisis and questions the sustainability of the current economic model of labour-intensive industrial activities. 
As a street located within the urban margins of Genk - in a space that is physically near to the centre, but perceptually distant from it - Vennestraat offers a particular contextual lens. This street is about 10-minute bus trip away from the city centre. It is a retail street and its space is of everyday inhabitation rather than symbolic occupation. Vennestraat hosts 65 dwellings. Among them, the old cinema building is now abandoned, two supermarkets (Colruyt and Aldi), a tattoo studio, 1 hairdresser and 58 retail shops. The street is known for its HoReCa segment, where retail shops, small businesses, offer a varied pallet of products, from Turkish, Italian traditional ones, to handmade art deco jewellery. While these shops are window fronts on the street, the rest of the dwelling, the upper floors (maximum two), are rented out to tenants. Vennestraat is a place to catch a bus, post a letter, top up a card and go to a café: an ordinary world where ordinary inhabitants of Genk engage in a type of social interaction. The street forms an alternative centre for the residential areas around it; it represents a space of economic exchange, increasingly and specifically for the migrant communities in Genk, located in the poorer area of the city. Even though it has a very mixed and vibrant economy, the street remains invisible. If 'cities are places where adding new work to older work proceeds vigorously' (Jacob, 1969, p. 50), understanding existing local dynamics by connecting work to its spatial dimension becomes crucial. We stress the importance dynamics have at the micro level by defining the city as 'a settlement that consistently generates its economic growth from its own local economy' (Jacob, 1969, p. 262). Given the intrinsic relation between spatial and economic developments, answering an economic crisis such as the one in Genk requires understanding these local economies - how to map and further track them - and investigate the alternative they give to the labour-intensive market.

\section{Methodology}

In order to understand how the local economies function, we mapped existing social and economic networks, guided by (1) the businesses logic (e.g., resources, partners, channels, activities, customer relationship/segment) and (2) the importance of social links described in the co-working model. We used a design anthropological approach (Gunn, Otto, \& Smith, 2013) that has been circulated among researchers to represent the diversity of ties in one's life since the seventies (Gunn, et al., 2013). Hand drawn maps of social connections, such as 'relational maps' (Bagnoli, 2009) establish new and creative methods of social networking examination and improve the comprehension upon the way people choose to display their networks. After providing pen and paper, Bagnoli asked the participants to reveal the relationships important to them, by placing themselves in the middle of the map and taking into consideration that the distance from the centre to each connection showed the strength of that particular connection. Alternatively, she allowed the participants to build personal representations in their own ways, providing 'basic scaffolding' (Prosser \& Loxley, 2008). Roseneil (2006) asks the participants during the interviews to create relational maps, by placing their social connections into concentric circles, again distance from the centre showing the degree of importance of that particular connection. The work of Roseneil is mostly in the therapeutic psychology field (psychosocial dynamics), but there are several analogous objectives, with participants asked to build visual patterns to illustrate their relationships, all with the aim of reaching hidden understandings. Ingold's correspondence (2013) is all about engaging with physical materials and arranging them into correspondence with one another. During the progression of the building process, pieces turn into parts that get to blend together. The maker can foresee a possible end of the process, but he cannot interfere by guiding materials into a precisely preconceived end. Ingold asks participants to create meaningful arrangements with the materials provided, that is a correspondence of foundation, pins, rubber bands and gestures. 
In our case study, we integrated a visualization tool in a participatory mapping activity. We adapted John Fass' Everybody Needs Somebody (2014) methodology to (1) support people in illustrating their networks, the aspects they want to show, and (2) to analyse the potential of these ties to shape dynamics of work. Fass uses pins and rubber bands in the pursuit of physical form definition and description. The pins on the map represent people and the stretched rubber bands represent the connections between them and the author of the map. This type of process reports in a language that allows for engagement regardless ones' background. Pin and rubber band maps have been used as methods of teaching mathematics. A Geo-board (Coleman, 1978), designed in the 1950s, is a mathematical calculating structure, which uses nails and rubber bands to build geometry concepts. It is good to know that the nodes on this type of map have a fixed position and cannot be adjusted by the user, as opposed to Fass' version. His method, Everybody Needs Somebody, displays ways in which people build privately meaningful recounts of their social networks by means of creating physical images of them with everyday materials. Fass argues that our existence, relationships and reasoning are defined by the people we know and the personal relationship we have with each of them, making us the centrepiece of our own complex web. Based on these connections, we make decisions as to where to live, study or work, and also our comprehension of the world is influenced. However, it is difficult to notice or distinguish the ways in which we are connected to other people, mostly due to the fact that such connections tend to modify all the time and also, they are complicated to display.

On an operational level, we used partly conducted interviews, analysis of the online activity of each shop over the past four years and direct observation. To enhance participation of the different proprietors to visualize, reflect and take action over the gathered qualitative data, we used the aforementioned mapping method. To allow the different dynamics to surface, we organized one-onone sessions in which each shop owner co-created a visual portrait of his/her business. This portrait visualized the shop in question and its socio-economic network of work (employees and customers). Fass' way of mapping provided us with the lens to disclose a detailed landscape of the socio-economic dynamics of work in Vennestraat, guided by a specific question: '(how) Can the capabilities and ties of each proprietor influence the scale and model of work?' Equally, the hands-on playful nature of the methodology incentivized them to continue and take part in future participatory processes related to work and spatial changes beyond this particular project.

\section{Portraying socio-economic networks of work}

We were faced with the challenge of addressing various proprietors that had to project the dynamics of their businesses and come to new ways of seeing the latent possibilities of their socio-economic networks of work. One of the most important aspects of externalization is creating physical things. In constructionism but also in other varied theories, externalization is seen as the process of turning internal structures, thoughts and processes palpable and visible. People's perception of the world is transformed into personal context by means of externalization (Bateson, 2000). The ability of a person, group, organization or institute to meet this objective is subject to a capacity-building process (Arnstein, 1969) and significant outcomes were noted when engaging with participatory means (Leforestier, 2009). However, such processes are often faced with lack of motivation among participants and inability to foster long-term engagement as the topic at hand may be too complex (e.g., depicting socio-economic networks of work). Trying to overcome these challenges, researchers and practitioners have been experimenting with different participatory forms that foster cooperation and understanding, such as playful activities, serious games and participatory mapping (Constantinescu, Devisch, \& Kostov, 2017). Accordingly, Fass' methodology gave us the optimal balance between abstraction and concreteness, complexity and simplicity, play and work. 
Each proprietor mapped the socio-economic network of his/her shop concentrating on both the microsocio level of the shop as well as on the bigger scope of its economic network of work. They were asked to visualize the different providers, human and nonhuman customers in relation to their shop, as well as their employees (Figure 1). Each shop owner was given everyday materials: a white A3 foam board, a set of pins and rubber bands of various colours. The pins were divided into different categories, depending on the colour: they were used to represent employees (blue), human customers (white) and nonhuman customers - other shops (pink) and providers (green). Red pins were used to position the shop for which the network was portrayed. The rubber bands marked the connections between the pins. Participants represented spatial distances, following real-life geographies, by placing pins on the board closer or further away from the one representing their shop. The use of familiar objects led to the qualities of surprise, discovery, play and engagement. The methodology simplified the topic such that each participant could: (1) grasp the meaning of networks and (2) easily depict the socioeconomic ties. Proprietors were engaged throughout the whole process due to the playful nature of the process that allowed them to experiment and represent notions that prior to the interviews, were thought of only theoretically. Participants talked about how the physical nature of the exercise influenced their work network topology anticipation and allowed them to visualize, reflect and understand the different dynamics they are part of. The physical objects allowed them to transform a mental construction into a detailed externalization.
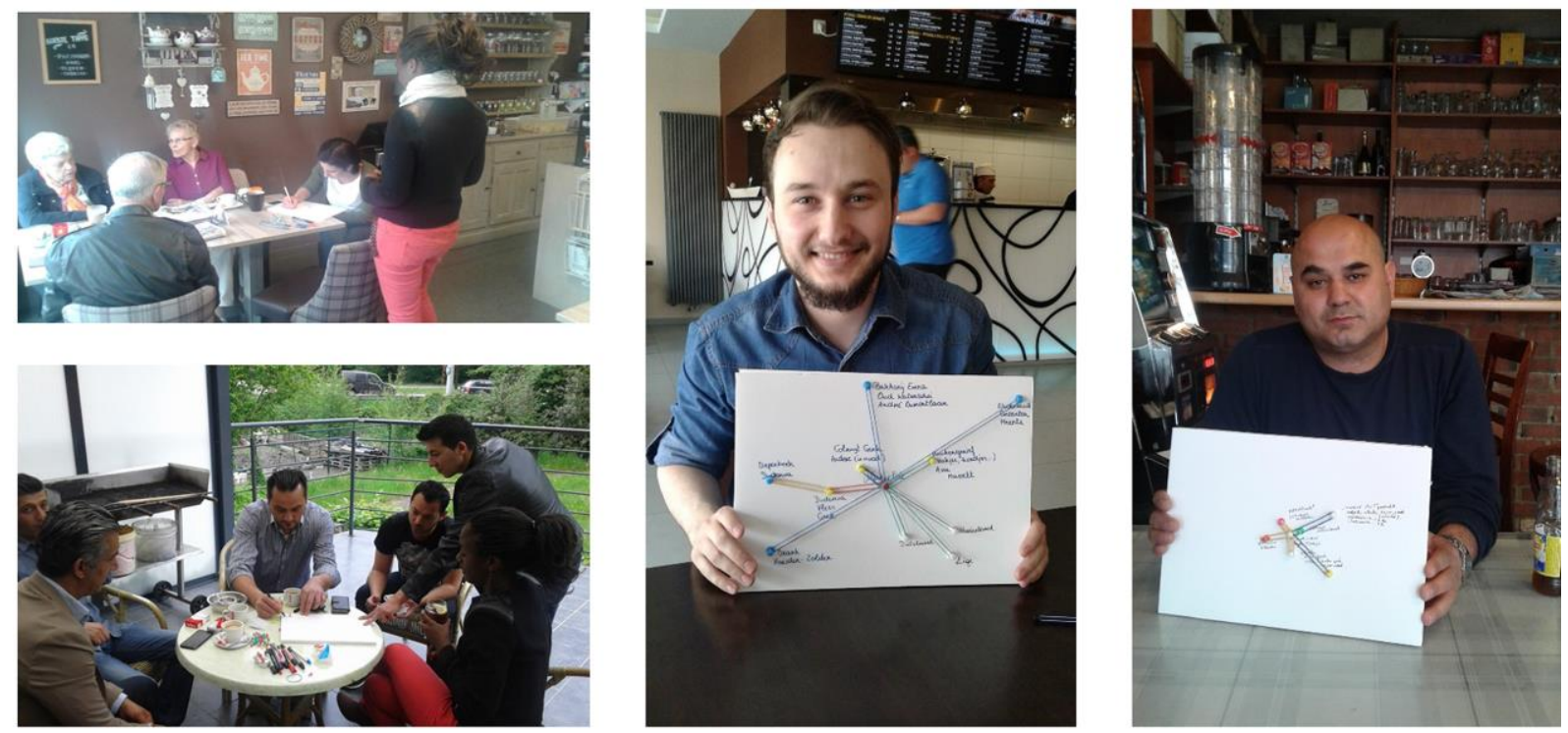

Figure. 1. Portraying socio-economic networks of work

The work networks came in a large range of different configurations (Figure 2). Most of the responses placed their shop in the middle of the relational map, with a radial arrangement. Variety comes from aspects like how many connections the portraits depict or whether the shops in a network are presented as connected to one another. Networks changed their shape and dimension when told stories about them: during interviews, proprietors changed the positions of the pins, in relation to the centre point and to each other. The exercise revealed an interesting dynamic of work: 50 shops from the total 58 portrayed are small family businesses that employ mainly family members. The shops have clear target clusters: they address mainly specific ethnic groups, as they sell specific products imported directly from their country of origin (e.g., Italy, Turkey, Morocco) (Figure 3). Most of the times (two out of five cases), the import network is established through a family member that remained in the 
country of origin. We equally observed that some shops use local providers that rarely expend beyond Genk, beyond the street itself actually. While one proprietor buys croissants from the vis-à-vis bakery and sells them with the morning coffee in his bar, another cooks the daily special with vegetables provided by the shop two doors down the street. The diverse profiles of the shops and their specificity attract customers from all over Limburg (Figure 4).
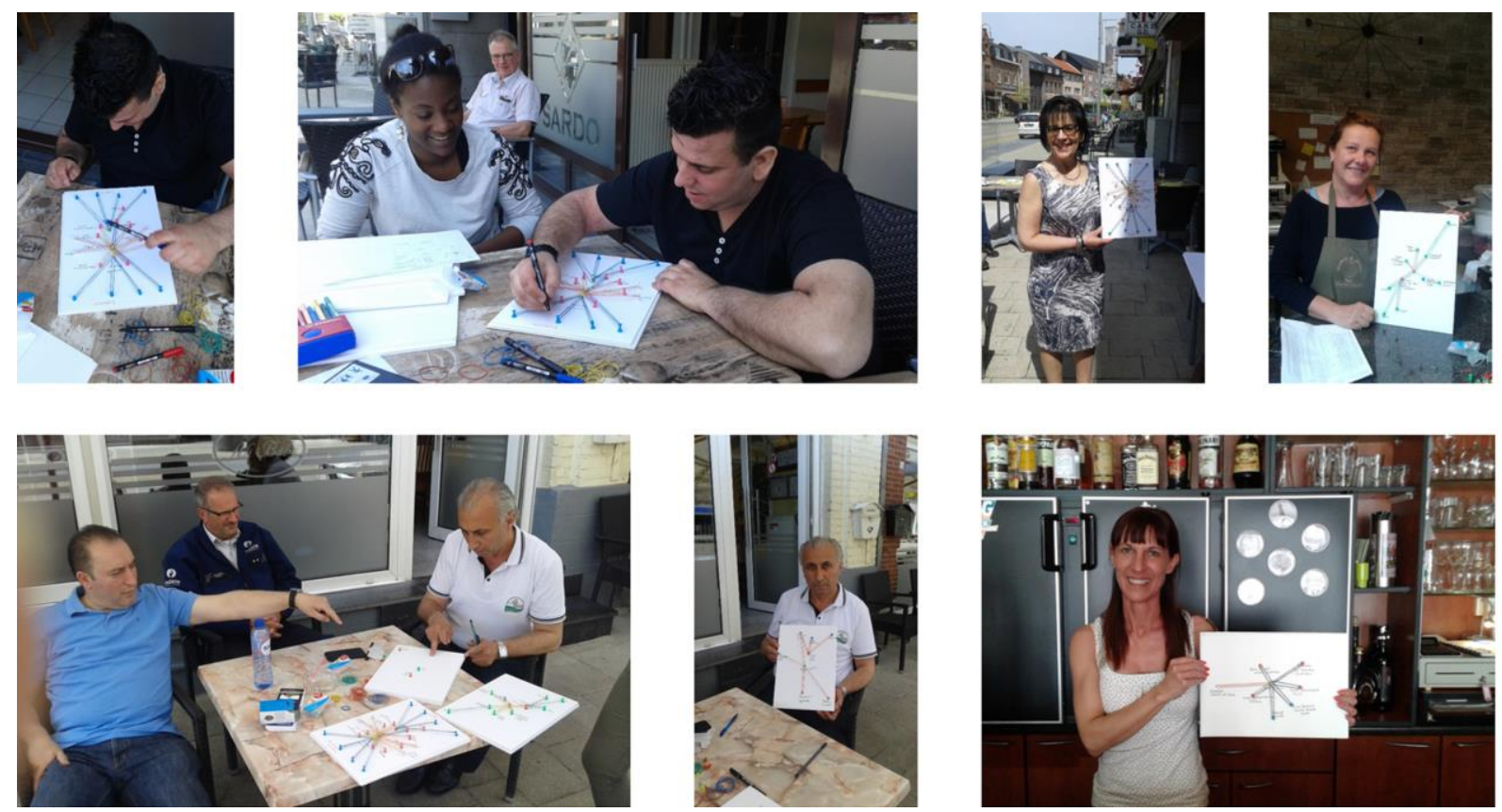

Figure 2. Portraying socio-economic networks of work

The participatory mapping exercise resulted in a database of different profiles: while some are complex, intricate representations of social and economic links, others depict simple, straightforward dynamics of work. There are multiple working clusters operating in parallel - different shops use the street simultaneously for similar purposes or for different ones: multicultural catering establishments combined with designer shops and boutiques. There is a strong link among shop owners of the same ethnic background. They usually organize closed events for small groups of the community after working hours using their shops, by rotation (e.g., Sunday barbeques, birthday parties, religious celebrations). This is specific to the Turkish community which functions following specific religious rules.

We can't always mix in the festivals and parties on the street. Our religion is sacred, our wives can't be exposed to certain things. We only marry girls of Turkish blood, we go back to Turkey and find a wife if we have to. I like to put my shop up for barbeques every other Sunday. It has a nice large garden in the back where we can gather with other families. (Kuthan, 36)

The other big minority on the street is the Italian one. If we analyse Angelos' work portrait, we see an intricate web of connections. Angelo is from the second generation of Sardinian migrants. He was born and raised in Winterslag, living just a couple of houses away from Vennestraat. He took over his father's shop who inherited it from his grandfather. He transformed it into a bar catering for the Italian community of Genk, as Angelo is one of its representatives in the dialogues with the Municipality. He serves mainly drinks and small snacks. The economic crises slowed down business for Angelo; he joined 
forces with the proprietor across the street, Luigi, who was facing the same economic difficulties. They took advantage of their gastronomic heritage and opened a restaurant on the street, two shops to the right from Angelo's bar. They became 'partners in crime' recognizing the added value of a collaboration.

I was struggling with the bar; the business was slower than usual and had no perspective. You know how Italians are, at least what is left from my Italian blood (he laughs), we like to complain. I told Luigi I might have to close down, he was as desperate as I was. And then... we just thought: what if? We could become partners in crime, said Luigi and we came up with this restaurant idea. We imagined we had more chances together and, we were right! (Angelo, 43)

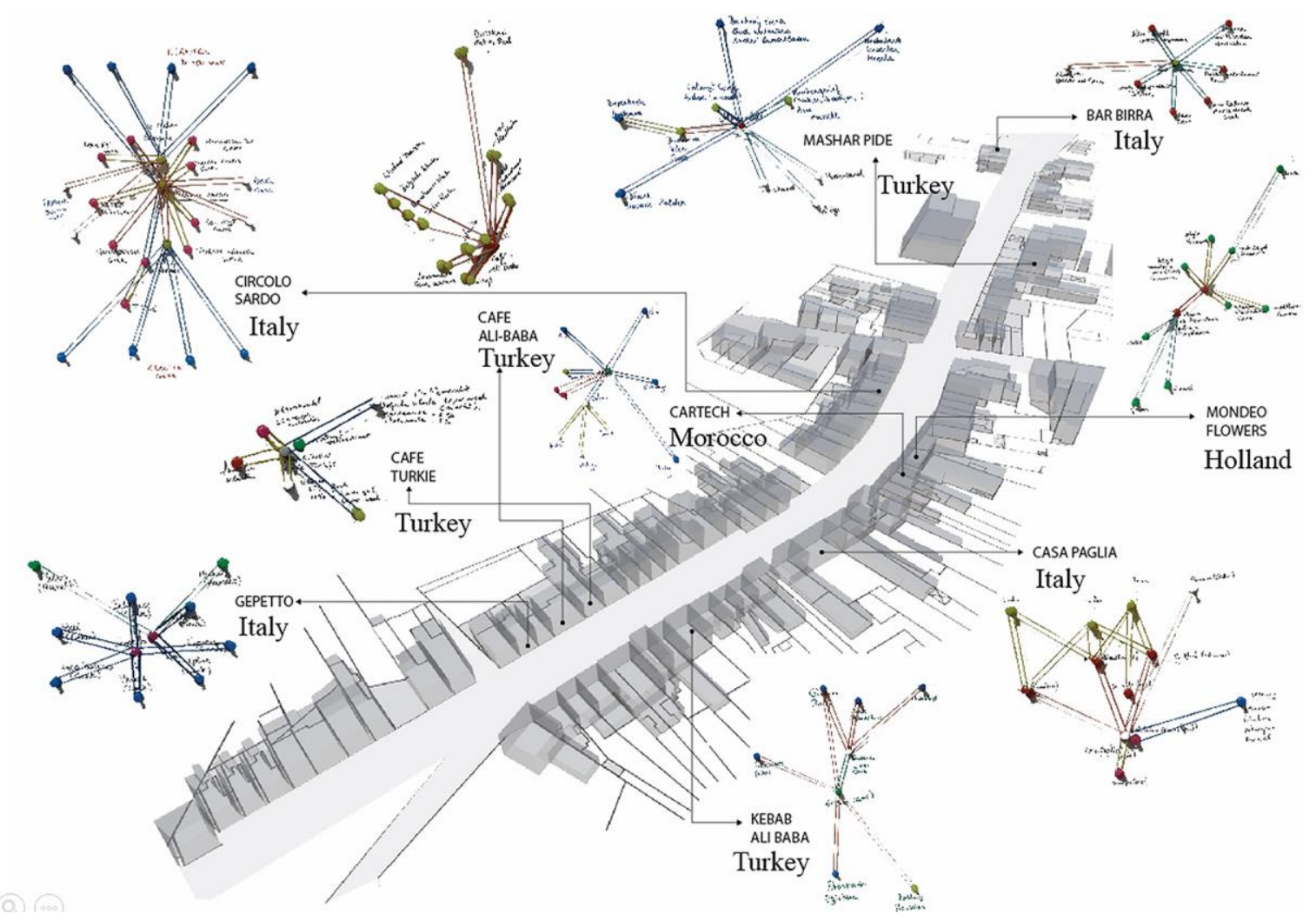

Figure 3. Vennestraat's multiculturality

In parallel, we conducted an analysis of the online activity of these shops in the past three years, starting from March 2014 and ending in March 2017. We found that, from all 57, only 16 have a website and/or social media profile (e.g., Facebook). We looked at the type of online activity (e.g., post text, photo, share, video and event), content and language (Figure 5). While only some shops would anticipate and post texts about the different activities proposed by their shop (e.g., Sunday drinks at the bar, new menu for the coming week, arrival of new products), they would all post photos and videos of these happenings after they took place. We could rarely see an online event addressing shops individually shared prior to the date; however, all shops, without exception, shared events of other shops and events which were to take place on the street (e.g., festivals). None of the websites and/or profiles provided the option of buying products online. 


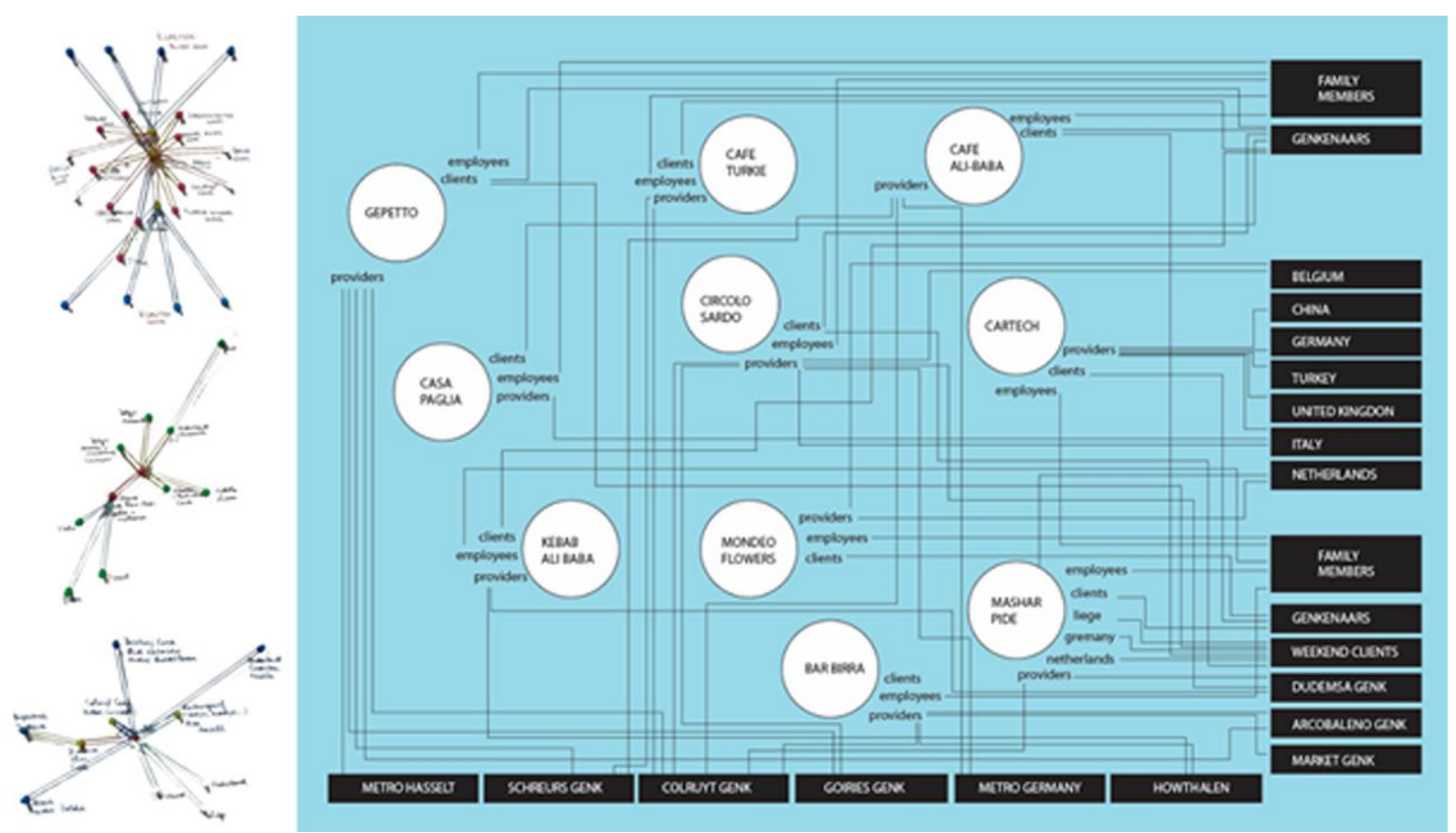

Figure 4. Socio-economic dynamics of work

Both part-conducted interviews and visual portraits as well as the online activity analysis describe strong community ties on which the proprietors relay for a good work performance. The research revealed three work types taking place on Vennestraat: from the online analysis, we could identify a (1) virtual (social) collaboration among entrepreneurs meant to support each other's business/activity. The part-conducted interviews and the visual portraits revealed a (2) work model based on economic collaborations within the street and a (3) work model based on economic collaboration within the same ethnic community. Even though somewhat different, the last two work types share the same space for their activity - the street (Vennestraat). Each shop is a privately owned independent small business; however, their working model functions in an 'open-source community approach' (Leforestier, 2009) - meant to be collaborative and to create communitarian social relations between members (e.g., shops). If we consider co-working spaces to be collective places, where co-workers function as complementary figures rather than challengers as defined previously, we observe that the street (Vennestraat) becomes the shared space where work is being shaped. Additionally, participants underlined the importance of the physical space as well as the 'reputation' of the street as a main element that shapes their daily activity.

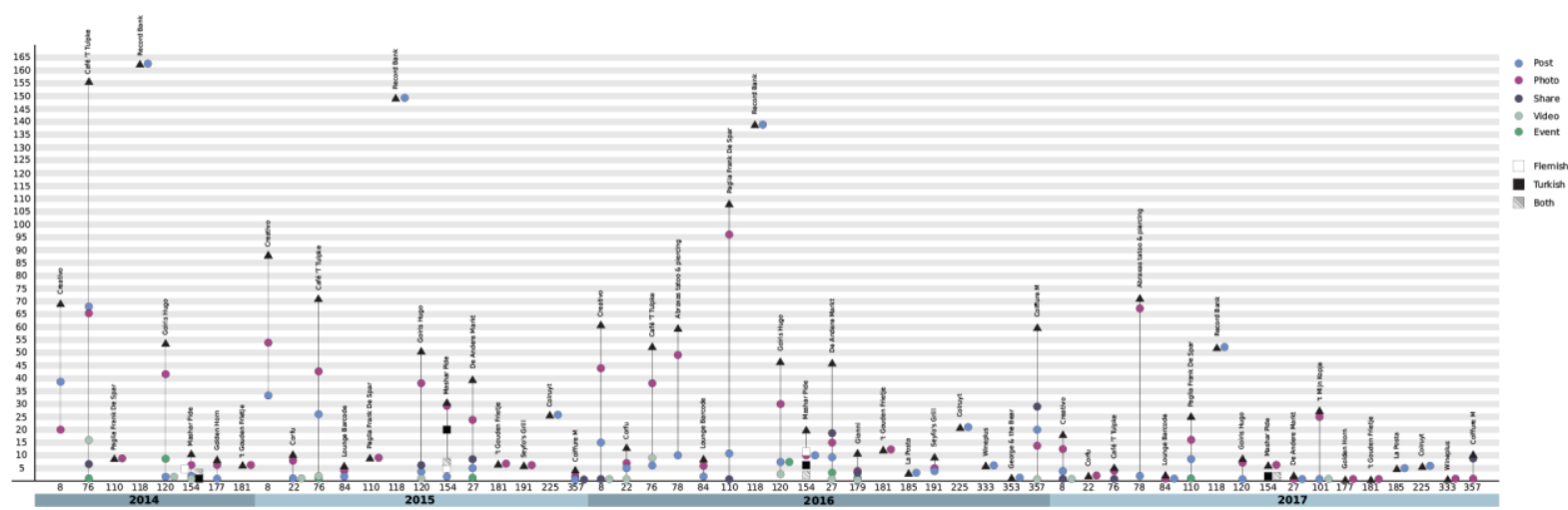

Figure 5. Shops' online activity 


\section{The role of the city in creating the 'reputation' of the street}

Trade, catering and tourism are an important employment engine for Genk (good for about 4500 jobs) and provide an urban experience. The municipality took the initiative for the (re)development of shopping and catering areas. Genk does not have a historic city centre and therefore misses catering in the centre, and as such, the city government focuses on the various urban trading centres, which are complementary developments. Vennestraat is a well-known shopping street, which knew its great growth at the time of the coal mine. After the closing of the mine, in the mid-1980s, the street started to decay. The vast majority of owners sold their trading houses. The commercial buildings were languishing, and Vennestraat was in decline. The street was shaped by different waves of entrepreneurs over the years, starting with a majority of Turks, followed by the Italians and, finally, making way to a multicultural mix of proprietors.

However, in the past decade, Vennestraat has been gradually upgraded starting with the arrival of Cmine in the immediate vicinity. C-mine (the former mine site) has been expanded as a cultural and tourist attraction. This expansion has created a positive spiral of more businesses and new art galleries that settled in Vennestraat. The city started a project of reconstruction for the street that was completed halfway through 2014. In addition to a general 'refresher' and beautification of the street, the city wanted to connect C-mine and Vennestraat more architecturally so that people would move more and more smoothly from C-Mine to Vennestraat, and vice versa. Together with the proprietors, the city also looked for a new interpretation of the street that attracts new businesses and offers customers a separate experience that brings them back into Vennestraat. The Saturday vegetable market held on the street made its appearance, as well as the Vollebak festival (a two-week festival that mobilizes all entrepreneurs). Consequently, Vennestraat is now explicitly promoted as a 'street of the senses', a street that brings a fascinating mix of multicultural catering establishments and shops in a popular atmosphere, combined with designer shops and boutiques. The intention is to create a balance in the new Vennestraat between design and the authenticity of the popular multicultural. More broadly, the city has promoted trade and catering as an asset deployment via a 'max of the mix' marketing strategy based on the multi-'culinarity' of the street. Additionally, the city gives subsidies to entrepreneurs that want to open a shop on Vennestraat, supporting the conversion costs of the dwellings (e.g., certain building standards imposed on façade renewal, exterior joinery, roofs, gardens, etc.). In recent years, high-rise buildings have also appeared on Vennestraat and several apartment buildings were erected there. They are mainly occupied by pensioners. The city council has recently taken the initiative to try and preserve the Garden District for posterity.

The municipality has deliberately played an active entrepreneurial role in the past decade as a motor for the economic development of the city. However, it is now about to let go of entrepreneurship and give space to the proprietors, to give responsibility back to the social and economic actors active on the street. By positioning itself at a greater distance, the city government can therefore concentrate more strongly on coordination, direction and making connections through network-oriented approaches that engage private and public actors in maintaining and developing the reputation of Vennestraat.

The city council in an active directing role, recognizes the importance of being sufficient in addition to the creative knowledge economy. As such, we continue to pay attention to the growth of earlier classic industrial activity as (1) an engine for employment in the short and medium term and (2) as a complementary addition to the knowledge-based businesses. (City councils' communication manager)

As a consequence, a street manager was appointed by the municipality and the merchant association was established. The merchant association is run by one of the proprietors designated through 
democratic vote by the other shop owners. They have monthly meetings, each month in a different shop, and discuss common concerns over their activity in the street. The association manages the activities that take place on Vennestraat. Both the street manager and the merchant association representative have the role to ease communication between proprietors and the city - and vice versa - concerning actions to be taken on the street (e.g., speed limit, parking slots, closing the street for car access on various occasions - festivals, Sunday market - signs entrepreneurs want to hang on their shop windows, activities proprietors want to engage in on the street, etc.).

\section{Reflections}

While Bagnoli was searching for creative tools development and personal networks classification system, Fass' approach is mostly interested in ways of externalizing networks. This tool revealed a particular dynamic among the different shops - they function more as an ecosystem (Grimm, Baker, \& Hope,2003) rather than a linear collection of entrepreneurs. The work networks illustrate a symbiosis between the different shops depicting a larger scale of a co-working phenomenon: the street (Vennestraat) represents the spatial dimension of work - the space they share to carry out their work. The proprietors/shops become individual workers that share the street, thus, the street becomes the co-working space. This co-working space is a collectively driven, networked space - a space shared by shops in search of autonomy and collective systems. This approach leads to the next question: Which features this street has (or should have) to increase the co-working potential?

The most important productivity factors in this co-working space are the social relations. The space of the street is intended as a collaborative environment where new production opportunities can be used by proprietors, in non-hierarchical situations. Their entrepreneurial activity is confined in a noncompetitive and widely 'socialized' philosophy of work, enacted in a context of production made of small-size actors. It does not function based on hierarchical relations. The co-workers, the individual shops in this case, cultivate social relations in a managerial way (the merchant association) in order to boost profits and business turnover. Co-workers function as complementary figures rather than challengers. This is called a logic of 'good neighbours' or 'good partners' approach, an organizational principle partially based on society, by which business development is obtained by collaborations of peers sharing the same work space - the street - originated from a mixture of correspondent skills and social relations (Spinuzzi, 2012). We observe a similarity with the 'networked mode of organization' strategy, a flexible way in between collaboration, cooperation and competition (Gandini, 2014). In this case, the unofficial interaction is more popular due to the unconstrained design of the organization.

Capdevila (2013) underlines the purpose of 'micro-clusters' in allowing information transfer among network members in his study concerning co-working practices from an organizational point of view. He talks about industrial clusters hosting firms and organizationsthat create and maintain network relations with each other in order to gain mutual trust. While on this topic of co-working's noncompetitive character, Capdevila portrays an intricate socio-economic situation originated in the active interaction of networks, described as a place that combines both traditional and modern organizational practices in a structure known as 'instrumentally coherent rationale' (Capdevila, 2013), that influences the social capital to search and use network resources in order to obtain some financial advantage. As a conclusion, co-workers get involved in the creation and perpetuation of trust relations between themselves, preferring to use techniques of negotiation than be part of competitive frameworks. Analogically, in our case study, the space of the street is hosting microbusinesses and proprietors that perform a multitude of tasks and actions in collaboration and coexistence. The importance of personal networks and social capital acquisition shapes the relations among shops and 
creates an opportunity to generate collaboration relations with complementary skilled colleagues (e.g., shops with a different profile) as a productivity element and an essential capitalization resource, along with building a reputation in a strategic 'business-like' manner. We witness that the co-working space of the street is able to design networks and 'new' social capital, based solely on reputation.

Everybody knows that Vennestraat is the place to be if you want to open a horeca business. (Jan, 36)

This street was always famous for its business. You don't need to do much, just find a nice window front and people will enter your shop - they are attracted by the multiculturalism of Vennestraat. (Maria, 53)

The streets' reputation has an 'intermediary' role in getting access to network resources and in obtaining financial outcomes; that is why maintaining it becomes the most important aspect proprietors strive for.

The role of space in the larger discourse of work types identified on Vennestraat is equally important as the aforementioned social aspect (e.g., reputation, social networks, trust). The recent refurbishment upgraded the public space by enlarging the pedestrian area in front of the shops, placing designed urban furniture that incites for longer stays, providing greenery and parking spaces along the street. The street is very well connected via public transport with the neighbourhood and the rest of the city. It has a speed limit of $30 \mathrm{~km} / \mathrm{h}$ and the parking places provided have a lower hourly price than the ones in the city centre. Equally, it is easily accessible by bike and/or foot. As such, people have a variety of mobility options.

To conclude, shops in the co-working space of the street relate to an integral 'economic rationale', where networking is considered to be appropriately functional in the reputation achievement process. The reputation of the street is also seen as the element which holds the various social peers in the same space and which is leading them towards the larger scene of the socio-economic segment of the city. As a result, the street serves not only as a work space but also as relational milieu which offers shops the best intermediary area to put their practices to use, permanently negotiating relationships in the given professional interaction context. This intermediary area is not just a stop-by work place with down to almost no professional interaction, but rather a space used mainly to create and cultivate network relations and to obtain a certain wanted position in the job market.

Finally, the co-working space of Vennestraat can bear a favourable role in being intermediate for value production, in addition to recreating the physical territory; this way, the street may sustain the recognition of mutual economic interest of the proprietors. As such, this street interpretation of coworking may offer an answer to (some of) the crises of global work trends (e.g., separation of work from time and space, challenges arising from the mobile character work is developing and its 'independence' from geography, etc.) if further researched.

\section{Funding}

The research was partly funded by the JPI Urban Europe Fund under the research project: Play!UC 'Playing with Urban Complexity: Using co-located serious games to reduce the urban carbon footprint among young adults'. 


\section{References}

Arnstein, S. R. (1969). A ladder of citizen participation. Journal of the American Institute of Planners, 35, 216-224.

Arvidsson, A. (2008). The ethical economy of customer coproduction. Journal of Macromarketing, 28(4), 326-338.

Bagnoli, A. (2009). Beyond the standard interview: The use of graphic elicitation and arts-based methods. Qualitative Research, 9, 547-570.

Bateson, G. (2000). Steps to an ecology of mind: Collected essays in anthropology, psychiatry, evolution, and epistemology. Chicago, IL: University of Chicago Press.

Birchall, J. (1997). The international co-operative movement. Manchester: Manchester University Press.

Botsman, R., \& Rogers, R. (2011). What's mine is yours: How collaborative consumption is changing the way we live. New York, NY: Collins.

Capdevila, I. (2013). Knowledge dynamics in localized communities: Coworking spaces as microclusters. Retrieved from http://ssrn.com/abstract=2414121

Cappelli, P., \& Keller, J. R. (2013). Classifying work in the new economy. The Academy of Management Review, 38(4), 575-596.

Coleman, D. B. (1978). Sketch, a geoboard game. Mathematics Magazine, 51(1), xxx.

Constantinescu, T., Devisch, O., \& Kostov, G. (2017). City makers: Insights on the development of a serious game to support collective reflection and knowledge transfer in participatory processes. International Journal of E-Planning Research, 6(4), 32-57.

Fass, J. (2014). Everybody needs somebody: Physical social networks \& visualisation. CX Program Royal College of Art Kensington Gore London, UK Arts and Humanities Research Council.

Foertsch, C., \& Cagnol, R. (2013). The history of coworking in a timeline, deskmag | coworking, Retrieved March 4, 2018, from http://www.deskmag.com/en/the-history-ofcoworking-spaces in-atimeline

Fost, D. (2008). They're working on their own, just side by side, New York Times, 20 February.

Gandini, A. (2014). The reputation economy: Creative labour and freelance networks (Doctoral dissertation, PhD in Sociology). University of Milan.

Gill, R. C., \& Pratt, A. C. (2008). In the social factory? Immaterial labour, precariousness and cultural work. Theory, Culture and Society, 25(1), 1-30.

Grimm, N. B., Baker, L. J., \& Hope, D. (2003). An ecosystem approach to understanding cities: familiar foundations and uncharted frontiers. In A. R. Berkowitz, C. H. Nilon, \& K. S. Hollweg (Eds.), Understanding urban ecosystems: A new frontier for science and education (pp. 95-114). New York: Springer-Verlag.

Gunn, W., Otto, T., \& Smith, R. C. (2013). Design anthropology: Theory and Practice. London: Bloomsbury Academic.

Hochschild, A. (1997). The time bind. New York, NY: Metropolitan Books. 
Howard, A. Ed. (1995). The changing nature of work. San Francisco, CA: Jossey-Bass.

Ingold, T. (2013). Making: Anthropology. Archaeology: Art and Architecture. Abingdon: Routledge.

Jacob, J. (1969). The economy of cities. New York: Random House, Inc.

John J. Heldrich Center for Workforce Development, University of Connecticut. Center for Survey Research \& Analysis. (2000). Nothing but Net: American Workers and the Information Economy. New Brunswick, NJ: Heldrich Center.

Kirsh, D. (2000). A few thoughts on cognitive overload. Intellectia, 1(30), 19-51.

Kling, R., \& Zmuidzinas, M. (1994). Technology, ideology, and social transformation: The case of computerization and work organization. Revue Internationale de Sociologie, 2-3, 28-56.

Lange, B. (2006). From cool Britannia to generation Berlin? Geographies of culturepreneurs and their creative milieus in Berlin. In C. Eisenberg, R. Gerlach, \& C. Handke (Eds.), Cultural industries: The British experience in international perspective. Humboldt University Berlin.

Lange, B. (2011). Re-scaling governance in Berlin's creative economy. Culture Unbound, 3, 187-208.

Leforestier, A. (2009). The co-working space concept.

Moriset, B. (2014). Building new places of the creative economy. The rise of coworking spaces. Proceedings of the 2nd Geography of Innovation, International Conference 2014, Utrecht, Netherlands: Utrecht University.

Osnowitz, D. (2010). Freelancing expertise: Contract professionals in the new economy. Ithaca: Cornell University Press.

Pratt, A. C. (2002). Hot jobs in cool places. The material cultures of new media product spaces: The case of south of the market, San Francisco. Information, Communication and Society, 5(1), 27-50.

Prosser, J., \& Loxley, A. (2008). Introducing visual methods. xxx: xxx http://eprints.ncrm.ac.uk/420/ 1/MethodsReviewPaperNCRM-010.pdf

Roseneil, S. (2006). The ambivalences of angel's "arrangement". The Sociological Review, 54(4), 847869.

Spinuzzi, C. (2012). Working alone together. Co-working as emergent collaborative activity. Journal of Business and Technical Communication, 26(4), 399-441.

Thompson, D. (1994). Cooperative principles then and now. Co-operative grocer. Minneapolis, MN: National Cooperative Grocers Association.

Watson, T. J. (2012). Sociology, work and organisation. USA: Routledge.

Womack, J. P., \& Jones, D. T. (2007). Lean Solutions, Simon \& Schuster, UK Ltd.

Womack, J. P., Jones, D. T., \& Ross, D. (1990). The machine that changed the world. Macmillan, NJ: Old Tappan. 